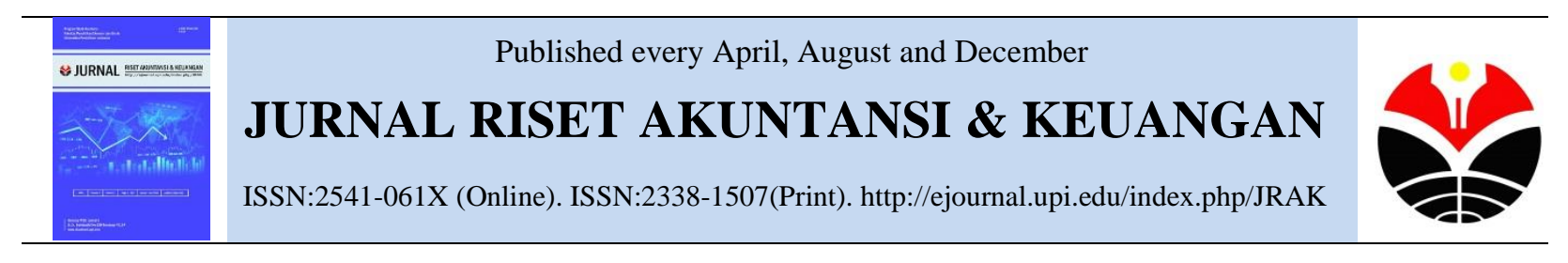

\title{
Keadilan Prosedur Dan Kepercayaan WP Terhadap Otoritas Pajak: Analisis Mediasi Kepatuhan Pajak
}

\author{
Riri Zemiyanti \\ Program Studi Akuntansi, FE, Universitas Islam “45” Bekasi, Bekasi, Indonesia
}

\begin{abstract}
The purpose of this is the influence of procedural justice on tax compliance through public confidence in the DJP. This study focus is on the SME sector because it would talk about PP 46 in 2013, and is expected to help policymakers in maximizing the potential taxation of SMEs. Based on this research, fairness heuristic theory argued that the procedural fairness of the tax authorities will increase taxpayer compliance. The study is also examine the mediating effect relationship justice against tax compliance procedures in the presence of public confidence in the tax authorities. This research is using survey, by distributing questionnaires to taxpayers SMEs. In this research there are validity and reliability test too. The analysis tool is use Structural Equation Modelling Partial Least Square (PLS-SEM using software WarpPLS 3.0. P. For the conclude of the research is show that procedural justice effect on tax compliance. Hypothesis two in this study also supported that procedural justice effect on tax compliance through the existence of public confidence in the tax authorities.
\end{abstract}

Keywords: Compliance; Tax SMEs; Fairness and Trust.

Abstrak. Tujuan dari hal ini adalah pengaruh keadilan prosedural terhadap kepatuhan pajak melalui kepercayaan masyarakat terhadap DJP. Fokus penelitian ini adalah pada sektor UKM karena akan membicarakan PP 46 pada tahun 2013, dan diharapkan dapat membantu pembuat kebijakan dalam memaksimalkan potensi perpajakan UKM. Berdasarkan penelitian ini, teori heuristik keadilan berpendapat bahwa keadilan prosedural otoritas pajak akan meningkatkan kepatuhan wajib pajak. Penelitian ini juga menguji independensi hubungan mediasi terhadap prosedur kepatuhan pajak dengan adanya kepercayaan publik terhadap otoritas pajak. Penelitian ini menggunakan survei, dengan menyebarkan kuesioner kepada pembayar pajak UKM. Dalam penelitian ini ada uji validitas dan reliabilitas juga. Alat analisisnya menggunakan Structural Equation Modeling - Partial Least Square (PLS-SEM menggunakan perangkat lunak WarpPLS 3.0 P. Untuk kesimpulan penelitian ini adalah menunjukkan bahwa efek keadilan prosedural terhadap kepatuhan pajak. Hipotesis dua dalam penelitian ini juga mendukung efek keadilan prosedural. Tentang kepatuhan pajak melalui adanya kepercayaan masyarakat terhadap otoritas pajak.

Kata Kunci: Kepatuhan; Pajak UKM; Keadilan dan Kepercayaan

Corresponding author. Email: zelmiyantiriri@gmail.com. Jalan Cut Mutia Raya No. 83, Margahayu, Bekasi Timur, Kota Bks, Jawa Barat 17113

How to cite this article. Zemiyanti, R. (2016). Keadilan Prosedur Dan Kepercayaan WP Terhadap Otoritas Pajak: Analisis Mediasi Kepatuhan Pajak. Jurnal Riset Akuntansi Dan Keuangan Program Studi Akuntansi Fakultas Pendidikan Ekonomi Dan Bisnis Universitas Pendidikan Indonesia, 4(3), 1101-1110. Retrieved from http://ejournal.upi.edu/index.php/JRAK/article/view/4662

History of article. Received: September 2016, Revision: November 2016, Published: December 2016

Online ISSN: 2541-061X.Print ISSN: 2338-1507. DOI: 10.17509/jrak.v4i3.4662

Copyright@2016. Published by Jurnal Riset Akuntansi dan Keuangan. Program Studi Akuntansi. FPEB. UPI 


\section{PENDAHULUAN}

Indonesia merupakan negara yang mengandalkan pendapatan pada sektor pajak. Total pendapatan Indonesia menunjukkan bahwa $73 \%$ pendapatan berasal dari sektor pajak (pendapatan dari sektor pajak Rp. 980.518.133.319.319,- dari total pendapatan Rp.1.338.109.629.172.958,- LKPP, 2012). Indonesia pada tahun 2012 mengalami defisit anggaran sebesar Rp 153,30 Trilliun. Pengurangan angka defisit dapat dilakukan dengan terus menggali sektor pajak. Peraturan Pemerintah (PP) No. 46 tahun 2013 merupakan salah satu usaha pemerintah untuk menggali sektor pajak, yang menyatakan bahwa setiap usaha masyarakat dengan omset di bawah 4,8 Milliar Rupiah dikenakan Pajak Penghasilan (PPh) final sebesar 1\%. Usaha yang omsetnya di bawah 4,8 M dikategorikan dalam Usaha Mikro, Kecil, dan Menengah (UMKM), sehingga UMKM menjadi target dari penerapan PP No. 46.

UMKM memberikan sumbangan PDB (Produk Domestik Bruto) lebih besar dibanding perusahaan besar. Sumbangan PDB dari sektor UMKM pada tahun 2012 sebesar 4.869.568,1 Milyar Rupiah, sedangkan perusahaan besar menyumbang 3.372.269,1 Milyar Rupiah. Pandapatan dari PDB akan berhubungan dengan jumlah potensi pajak yang akan diterima negara. Berdasarkan data di atas UMKM memiliki potensi pendapatan pajak yang cukup besar sebagai penyumbang pendapatan Negara.

Keunggulan UMKM tidak hanya dari segi pendapatan UMKM yang besar. Beberapa penelitian terdahulu mencoba menjelaskan beberapa keunggulan UMKM. Campin et al. (2013) menyatakan bahwa UMKM memiliki potensi untuk meningkatkan kesejahteraan masyarakat. Menurut hasil penelitian yang dilakukan oleh Hendrict et al. (1997) pertumbuhan UMKM lebih besar dibanding perusahaan besar. Keunggulan lain dari UMKM adalah menciptakan lapangan pekerjaan baru (Chen et al., 2002 dan Praag, 2007).

Potensi pendapatan dan beberapa keunggulan UMKM di Indonesia ternyata tidak sebanding dengan pajak yang diterima negara dari sektor UMKM. Fuad Rahmany, Direktur Jenderal Pajak (Dirjen Pajak) Kementerian Keuangan menyatakan bahwa hingga akhir tahun 2013 penerimaan pajak yang berasal dari sektor UMKM masih di bawah 2\% atau sebesar Rp 20,5 triliun dari total potensi penerimaan pajak (Zatnika, 2014). Angka tersebut masih jauh dari potensi pajak UMKM, sehingga membuktikan rendahnya tingkat kepatuhan pengusaha UMKM membayar pajak. Penerapan PP 46 tahun 2013 sudah efektif semejak juli tahun 2013 tetapi data di atas membuktikan penerapan PP 46 ini masih belum bisa menambah pendapatan negara dari sektor UMKM.

Jumlah pajak yang diterima negara dari sektor UMKM masih sangat sedikit, dibandingkan potensi yang ada. Pajak UMKM berdasarkan PP 462016 yang berdasarkan omset sampai saat ini masih belum maksimal penerapannya. Masih banyak pro dan kontra terhadap penerapan PP 46 disatu sisi pemerintah harus menggali sumber penerimaan negara disisi lain pemilik UMKM ketika dibebankan pajak akan menambah biaya industri sehingga laba bersih yang dihasilkan akan berkurang. Apalagi penerapan PP 46 ini berdasarkan omset UMKM ketika UMKM yang omsetnya tinggi belum tentu memiliki laba yang tinggi. UMKM yang posisinya masih belum tentu laba sudah dibebankan pajak, sehingga UMKM tersebut akan sulit untuk tumbuh. Penerapan PP No. 46 tahun 2013 yang sudah efektif semejak juni 2013 masih dipertanyakan mengenai keadilan, sampai saat ini masih menjadi perdebatan. Hal ini muncul karena masyakat merasa bahwa pengenaan pajak berdasarkan omset akan menimbulkan biaya lebih, terutama terhadap usaha dagang.

Penelitian yang dilakukan oleh Molero dan Pujol (2012) menyatakan alasan pengusaha tidak membayar pajak karena manfaat yang dirasakan tidak sebanding dengan biaya yang dikeluarkan. Sejalan dengan hasil penelitian Molero dan Pujol, ada PP 46 tahun 2013 belum temukan batasan minimal omset dan lama berdiri usaha, sehingga bagi usaha yang baru berkembang 
ketika dibebankan biaya akan mengurangi laba yang akan diperoleh dan untuk pengembangan lebih lanjut dananya akan terbatas. Penelitian yang dilakukan Kamleitner et al. (2010) menemukan persepsi pengusaha kecil bahwa ketika mereka membayar pajak merupakan sebuah kerugian yang menambah biaya industri. Pada saat usaha baru berkembang seharusnya pemerintah mendukung dengan memberikan berbagai fasilitas sehingga usaha tersebut bisa berkembang lebih bagus. Hal tersebut mengindikasikan bahwa keadilan pada sistem perpajakan di indonesia masih kurang, sehingga faktor keadilan akan mempengaruhi kemauan seseorang untuk membayar pajak.

Masalah lain yang menyebabkan rendahnya kepatuhan pajak karena tingkat kepercayaan masyarakat terhadap otoritas pajak sudah mulai berkurang. Kasus-kasus pengelapan pajak, seperti kasus Gayus menimbulkan opini pada masyarakat, pembayaran pajak yang dilakukan WP hanya dimanfaatkan oleh oknum-oknum tertentu. Oleh karena itu, tingkat kepatuhan pajak rendah tidak hanya karena keadilan yang dirasakan WP masih kurang tetapi juga karena tingkat kepercayaan WP terhadap otorias pajak sudah mulai menurun. Penelitian yang dilakukan oleh Gobeno dan Marius (2015) membuktikan bahwa keadilan prosdur akan meningkatkan kepatuhan pajak, melalui kepercayaan masyarakat terhadap Direktorat Jendral Pajak (DJP) . Penelitian tersebut dilakukan terhadap pemilik bisnis dinegara Ethopia yang masih baru berkembang.

Penelitian saat ini akan mencoba merujuk penelitian yang dilakukan oleh Gobeno dan Marius (2015) hal tersebut dilakukan karena pemerintah pada tahun 2013 baru mengeluarkan PP 46 yang berhubungan dengan pajak UMKM. Penelitian ini akan melihat pengaruh keadilan terhadap kepatuhan wajib pajak melalui kepercayaan masyarakat terhadap DJP.

Tujuan dari penelitian ini untuk menguji secara empiris mengenai pengaruh keadilan prosedur terhadap kepatuhan pajak melalui kepercayaan masyarakat terhadap DJP.
Penelitian ini difokuskan pada sektor UMKM karena akan mengupas PP 46 tahun 2013, diharapkan dapat membantu penentu kebijakan dalam memaksimalkan potensi perpajakan UMKM.

\section{KAJIAN LITERATUR}

\section{Usaha Mikro, Kecil dan Menengah}

Menurut Undang-Undang No 20 tahun 2008 tentang Usaha Mikro, Kecil, dan Menengah Pasal 1 menjelaskan bahwa pengertian dan kriteria Usaha Mikro, Kecil, dan Menengah uaitu (1) Usaha Mikro adalah usaha produktif milik orang perorangan dan/atau badan usaha perorangan dengan kriteria kekayaan bersih paling banyak Rp50.000.000,00 tidak termasuk tanah dan bangunan tempat usaha serta hasil penjualan paling banyak Rp 300.000.000,- (2) Usaha Kecil adalah usaha ekonomi produktif berdiri sendiri, dilakukan oleh orang perorangan atau badan usaha yang bukan merupakan anak perusahaan atau bukan cabang perusahaan. Kriteria kekayaan bersih Rp 50.000.000,00 Rp 500.000.000,- tidak termasuk tanah dan bangunan serta hasil penjualan tahunan Rp300.000.000,00 - Rp 2.500.000.000,00 (3) Usaha Menengah adalah usaha ekonomi produktif berdiri sendiri, dilakukan oleh orang perorangan atau badan usahabukan merupakan anak perusahaan atau cabang perusahaan

Kriteria usaha menengah kekayaan bersih $\mathrm{Rp} 500.000 .000,00 \quad-\mathrm{Rp}$ 10.000.000.000,00 tidak termasuk tanah dan bangunan serta memiliki hasil penjualan Rp 2.500.000.000,00 - Rp50.000.000.000,00.

Pajak UMKM merupakansalah satu bagian dari pajak pusat.Potensi pajak UMKM sangat tinggi seiring dengan perkembangan UMKM saat ini. Peraturan tentang kewajiban UMKM membayar pajak akan memberikan keuntungan bagi pemilik UMKM karena secara tidak langsung harus membuat laporan omset. Catatan omset tersebut akan membantu pemilik UMKM untuk memantau perkembangan usaha.

\section{Kepatuhan Pajak}


Pajak menurut ketentuan umum dan tata cara perpajakan, merupakan kontribusi wajib pajak kepada negara yang terutang oleh orang pribadi atau badan bersifat memaksa berdasarkan undang-undang, dengan tidak mendapatkan imbalan secara langsung dan digunakan untuk keperluan negara bagi sebesar-besarnya kemakmuran rakyat. Menurut kamus Umum Bahasa Indonesia (KBBI) patuh artinya suka dan taat kepada perintah atau aturan, dan berdisiplin. Harinurdin (2009) menjelaskan kepatuhan pajak (tax compliance) adalah sebagai kondisi ideal Wajib Pajak yang memenuhi peraturan perpajakan serta melaporkan penghasilannya secara akurat dan jujur. Dari pengertian di atas dapat simpulkan kepatuhan pajak merupakan kondisi ideal yang harus dilakukan oleh wajib pajak untuk melaporkan penghasilan secara akurat dan jujur, pemungutan pajak juga berdasarkan peraturan atau hukum, serta bertujuan untuk keseimbangan ekonomi.

\section{Fairness Heuristic Theory (Teori Heuristik Keadilan)}

Penelitian ini akan melihat dari aspek keadilan prosedur. Fairness heuristic theory adalah kesadaran bahwa hampir semua hubungan social dan lingkungan ditandai dengan apa yang disebut dilema social yang mendasar Lind (2001). Individi membuat penilaian keadilan yang bisa mereka gunakan sebagai heuristic untuk menentukan sejauhmana mereka dapat percaya bahwa lingkungan social mereka aman untuk keterlibatan bersama.

Teori heuristic keadilan menjelaskan perilaku wajib pajak dalam memenuhi kewajiban pajaknya. Seseorang akan taat membayar pajak pada tepat waktu jika orang tersebut memandang pihak yang berwenang (otoritas pajak) disini DJP, memberlakukan semua individu dengan cara yang sama dan tidak memanfaatkan atau mengambil keuntungan dari pajak yang telah dibayarkan oleh orang tersebut

\section{Teori Slippery Slope}

Pada masyarakat modern tingkat kepatuhan pajak bukan lagi kepatuhan yang dipaksa tetapi sudah beralih pada kepatuhan sukarela masyarat sudah mulai sadar untuk membayar pajak. Penelitian kepatuhan pajak tidak hanya dilihat dari faktor detterence (seperti denda dan pemeriksaan) tetapi kepatuhan pajak juga dapat dilihat dari psikologi sosial. Salah satu teori yang melihat kepatuhan pajak dari faktor detterence dan faktor psikologi sosial yaitu teori slippery slope model dari Kirchler et al. (2008). Teori ini menyatakan bahwa kepatuhan pajak dipengaruhi oleh variabel detterence dan psikologi sosial. Variabel psikologi sosial akan mempengaruhi kepatuhan pajak secara sukarela tetapi faktor detterece akan mempengaruhi kepatuhan pajak karena keterpaksaan atau adanya rasa takut. Rasa takut yang timbul bisa saja karena takut diperiksa ataupun didenda sehingga masyarakat tetap akan membayar pajak. Kebijakan untuk meningkatkan kepatuhan pajak secara sukarela tergantung pada tingkat kepercayaan masyarakat terhadap otoritas pajak, ketika tingkat kepercayaan masyarakat terhadap otoritas pajak masih tinggi maka tingkat kepatuhan juga akan tinggi

\section{Penelitian Terdahulu}

Penelitian Kamleitner et al. (2010) melihat kepatuhan pajak pada pemilik usaha kecil. Hasil penelitian Kamleitner et al. (2010), menyatakan ada tiga aspek kunci yang menyebabkan pengusaha kecil tidak patuh. Tiga aspek tersebut yaitu pengusaha merasa memiliki peluang untuk tidak patuh dibanding pekerja, rendahnya pengetahuan, dan frame dari pengusaha bahwa pembayaran pajak merupakan keputusan yang merugikan. Penelitian mengenai faktor yang dapat meningkatkan kepatuhan pajak UMKM sangat dibutuhkan untuk memberikan kesempatan wajib pajak UMKM berkontribusi secara langsung terhadap negara dan juga dapat mengajarkan pemilik UMKM lebih teliti dalam memantau omset.

Pertiwi (2013) melakukan penelitian mengenai kepatuhan pajak dengan melihat dari justifikasi pengelakan pajak. Penelitian 
tersebut dilakukan terhadap mahasiswa karena belum mempunyai Nomor Pokok Wajib Pajak (NPWP). Hasil penelitian menyatakan bahwa keluhan dalam makna absolut dan keluhan dalam makna relatif berpengaruh negatif terhadap kepatuhan melalui justifikasi pengelakan pajak. Rasa tanggung jawab dan rasa solidaritas berpengaruh positif terhadap kepatuhan melalui justifikasi pengelakan pajak.

Budiningrum (2014) melakukan pengujian secara komprehensif norma-norma sosial yang meliputi norma deskriptif, norma penangguhan, norma subyektif, dan norma pribadi dalam meningkatkan kepatuhan pajak UMKM. Penelitian tersebut dilakukan dengan metode survei terhadap 105 unit UMKM. Pengujian hipotesis dalam penelitian menggunakan Structural Equation Modeling (SEM) untuk melihat pengaruh langsung maupun tidak langsung setiap variabel. Hasil penelitian menyatakan bahwa norma deskriptif dan norma pribadi tidak signifikan berpengaruh langsung terhadap kepatuhan pajak. Norma penangguhan dan subyektif signifikan berpengaruh langsung terhadap kepatuhan. Norma deskriptif tidak signifikan berpengaruh tidak langsung tehadap kepatuhan pajak melalui norma penangguhan, norma subyektif, dan norma pribadi. Norma penangguhan tidak signifikan berpengaruh tidak langsung terhadap kepatuhan pajak melalui norma subyektif dan norma pribadi. Norma subyektif tidak signifikan berpengaruh tidak langsung melalui norma pribadi.

Penelitian yang dilakukan Gobena dan Marius (2015) melihat kepatuhan pajak dari aspek kekuatan, keadilan dan kepercayaan masyarakat pada Negara Ethopia. Penelitian tersebut dilakukan dengan metode survei terhadap 231 perusahaan besar dan kecil di Negara berkembang. Penelitian tersebut berhasil membuktikan bahwa kepatuhan pajak dipengaruhi oleh keadilan, kepercayaan, kekuatan peraturan.

\section{Pengembangan Hipotesis}

\section{Hubungan keadilan prosedur dengan kepatuhan pajak}

Teori keadilan heuristic menyebutkan bahwa individu membuat penilaian keadilan yang bisa mereka gunakan sebagai heuristic untuk menentukan sejauhmana mereka dapat percaya bahwa lingkuangan sosial aman untuk keterlibatan bersama (Lind, 2001). Pembayar pajak akan taat untuk membayar pajak jika orang tersebut memandang otoritas pajak memperlakukan semua individu dengan cara yang sama. Dana yang disetorkan wajib pajak digunakan untuk kesejahteraan masyarakat bukan dimanfaatkan untuk kepentingan pribadi.

Teori keadilan heuristic relevan untuk menjelaskan perilaku kepatuhan wajib pajak dalam mematuhi kewajiban perpajakan berdasarkan pandangan terhadap keadilan prosedur dari otoritas pajak. Prosedur dianggap lebih adil ketika seseorang diperbolehkan mengeluarkan pendapat dalam keputusan otoritas dan ketika pihak berwenang mengambil keputusan secara akurat dan tanpa memperhatikan kepentingan sendiri (Verboon dan Dijke, 2011). Beberapa penelitian Gobena dan Marius (2015), Murphy dan Tyler (2008), dan Wenzel (2004) berhasil membuktikan bahwa keadilan prosedur otoritas pajak berpengaruh positif terhadap kepatuhan pajak.

Berdasarkan teori heuristic keadilan menyatakan bahwa adanya prosedur yang adil dari otoritas perpajakan akan meningkatkan kepatuhan wajib pajak. Salah satu bentuk keadilan dengan diperbolehkan wajib pajak untuk memberikan pendapat. Pemungutan pajak di Indonesia yang mengunakan system self assessment memberikan kesempatan wajib pajak untuk menghitung, melaporkan menyetorkan pajak sendiri. Oleh karena itu dapat dirumuskan hipoteses sebagai berikut:

$\mathrm{H}_{1}$ : Keadilan prosedur berpengaruh signifikan positif terhadap kepatuhan pajak

\section{Hubungan keadilan prosedur terhadap kepatuhan pajak melalui kepercayaan}

Hubungan keadilan prosedur dan kepercayaan terhadap otoritas pajak juga dapat dijelaskan oleh teori fairness heuristic (Lind, 2001). Teori ini menyatakan bahwa masyarakat yang merasakan keadilan dari otoritas perpajakan akan mempengaruhi 
tingkat kepercayaan masyarakat sehingga tingkat kepatuhan pajak juga akan mengalami peningkatan. Kepercayaan merupakan salah satu dari aspek yang membangun kehidupan sosial yang merupakan sebuah elemen dari realitas sosial. Slippery slope model (Kirchler, et al. 2008) mendukung teori fairness heuristic kebijakan untuk meningkatkan kepatuhan sukarela tergantung pada tingkat kepercayaan masyarakat pada otoritas pajak. Masyarakat yang merasakan keadilan akan patuh terhadap kewajiban perpajakan tetapi dengan adanya kepercayaan masyarakat terhadap otoritas pajak kepatuhan yang muncul tidak hanya kepatuhan yang dipaksakan tetapi akan memunculkan kepatuhan sukarela.

Hasil penelitian yang dilakukan oleh Murphy (2004) membuktikan bahwa kepercayaan terhadap otoritas pajak juga memediasi pengaruh keadilan prosedur pada kepatuhan pajak. Sejalan dengan penelitian yang dilakukan oleh Gobeno dan Marius (2015) membuktikan bahwa adanya hubungan antara keadilan prosedur terhadap kepatuhan pajak melalui adanya kepercayaan masyarakat terhadap otoritas pajak. Hubungan keadilan terhadap kepatuhan pajak akan semakin bagus dengan tingginya tingkat kepercayaan masyarakat terhadap otoritas pajak.

Berdasarkan dua teori yang telah dikemukakan di atas dan beberapa penelitian terdahulu maka penulis akan melihat tingkat kepatuhan pajak yang didasarkan tingkat keadilan dan kepercayaan. Setiap wajib pajak yang diperlakukan secara adil WP tersebut akan percaya terhadap otoritas pajak sehingga ketika WP dituntut untuk membayar pajak mereka akan patuh. Oleh karena itu tingkat kepatuhan pajak akan lebih bagus dengan adanya keadilan dari otoritas pajak, sehingga dapat dihipotesiskan,

$\mathrm{H} 2$ : Keadilan prosedur mempengaruhi tingkat kepatuhan wajib pajak dengan adanya kepercayaan masyarakat terhadap otoritas pajak.

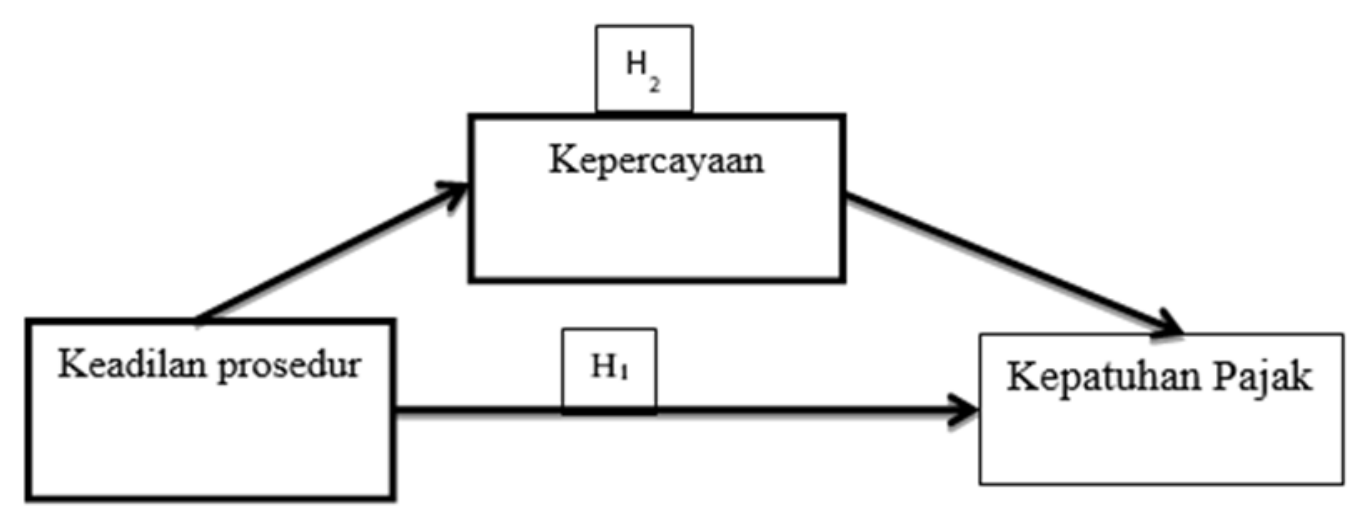

\section{Gambar 1. Desain Penelitian}

\section{METODOLOGI PENELITIAN}

Populasi dalam penelitian ini adalah Wajib Pajak yang penghasilannya berasal dari pekerjaan bebas (pelaku UMKM) di Daerah Bekasi. Pengambilan sampel dalam penelitian ini dilakukan secara nonprobabilitas (non random). Kriteria sampel pada penelitian ini adalah pemilik UMKM yang memiliki omset di bawah 4,8 Millyar hal tersebut dilakukan karena sesuai dengan batas omset PP 46 tahun
2013 yang dibebani pajak 1\% dari omset. Metode pengumpulan data dalam penelitian ini melalui survey.

\section{Definisi operasional dan pengukuran Kepatuhan pajak}

Secara spesifik akan dibatasi pengertiannya pada penelitian ini sebagai tindakan membayar pajak dengan jumlah yang tepat. Kepatuhan pajak bisa dilihat dari voluntary tax compliance dan enforced tax compliance. 
Indikator untuk mengukur kepatuhan pajak difokuskan pada voluntary tax compliance.

\section{Keadilan Prosedur}

Keadilan prosedur yaitu keadilan yang diterima oleh wajib pajak mulai dari informasi yang diterima apakah otoritas perpajakan memberikan informasi secara merata dan dilihat juga dari apakah otoritas

pajak sudah menggunakan informasi yang valid dalam mengambil keputusan. Indikator untuk mengukur keadilan: neutrality (bias suppression), fairness of tax authority, respect, trustworthy treatment from the tax authority, and consultation.

\section{Kepercayaan}

Kepercayaan merupakan seberapa besar masyarakat memiliki nilai kepercayaan terhadap otoritas perpajakan. Indikator untuk mengukur kepercayaan wajib pajak affectbased trust and cognition based trust.

\section{Teknik Analisis}

Penelitian ini dilakukan dengan mengunakan metode survai dengan menyebar kuesioner terhadap wajib pajak. Penelitian ini akan mengunakan alat analisis Structural Equation Modelling - Partial Least Square (SEM-PLS) menggunakan software WarpPLS 5.0. P. Hal ini dilakukan karena model teoritis variabelvariabel yang tidak bisa diukur secara langsung atau disebut konstruk. SEM mempunyai kelebihan karena memperhitungkan adanya kesalahan pengukuran untuk variable-variabel yang tidak bisa diukur secara langsung (Heir et., al. 2014). Selain itu, SEM juga bisa untuk menilai kesesuaian model (model fit).

\section{HASIL DAN PEMBAHASAN}

\section{Pengaruh Keadilan Prosedur Terhadap Kepatuhan Pajak Sukarela}

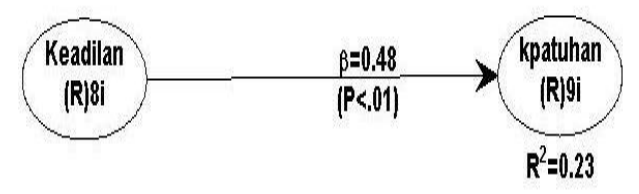

\section{Gambar 2. Pengaruh Langsung}

Gambar di atas menunjukan bahwa keadilan berpengaruh terhadap kepatuhan pajak ini bisa dilihat dari $\mathrm{P}$ value lebih kecil dari 0,05 sehingga hipotesis satu diterima. Nilai R-Squre sebesar 0.23 atau $23 \%$ menunjukan keadilan prosedur mempengaruhi pajak sebesar $23 \%$, sisanya dipengaruhi oleh variabel lain. Penelitian ini mendukung teori heuristik karena orang yang diperlakukan secara adil akan terlibat pada masyarakat, sehingga jika dihubungkan pada kepatuhan pajak orang akan taat dan patuh ketika sudah diberlakukan secara adil. Masyarakat merasa mendapatkan perlakuan yang adil ketika disaat mereka membayar pajak mereka juga mendapatkan fasilitas dari negara. Hipotesis ini terdukung karena sekitar 91,43\% responden yang peneliti dapatkan mengikuti organisasi UMKM. Ketika responden mengikuti organisasi UMKM mereka akan mendapatkan berbagai pelatihan dan kegiatankegiatan dari dinas kopersi dan UKM. Oleh karena itu penelitian ini mendukung beberapa penelitian sebelumnya seperti penelitian Gobena dan Marius (2015), Murphy (2004) dan Tyler (1997), dan Wenzel (2002) berhasil membuktikan bahwa keadilan prosedur otoritas pajak berpengaruh positif terhadap kepatuhan pajak. 


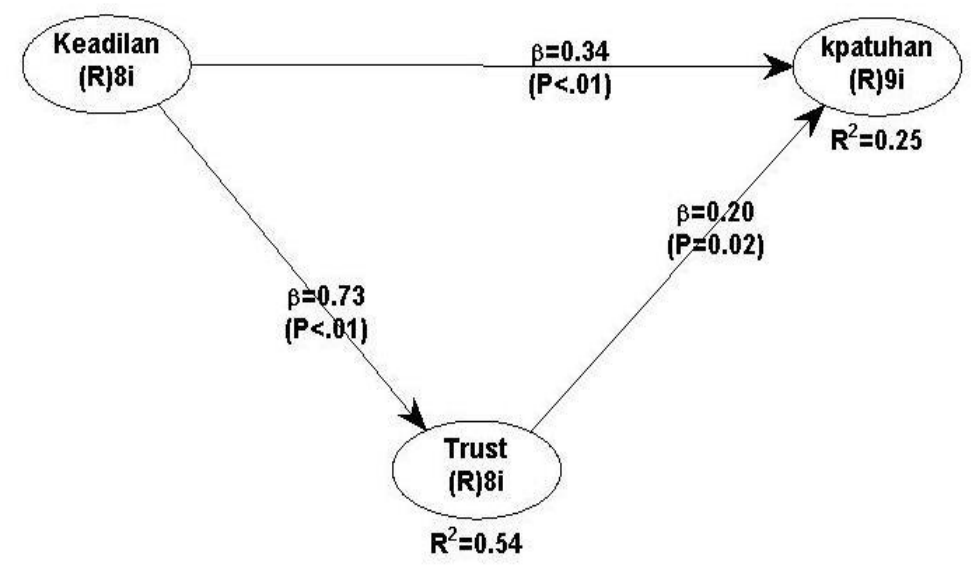

Gambar 3. Uji Pengaruh Mediasi

Efek mediasi bisa dilihat dari nilai Beta pada gambar satu 0.48 , pengaruh langsung keadilan terhadap kepatuhan pajak sedangkan pada gambar dua nilai beta menunjukan 0.34 tetap signifikan. Oleh kerena itu efek mediasi yang muncul disini yaitu mediasi sebagian (partial mediation), menunjukan kepercayaan memediasi hubungan keadilan terhadap kepatuhan pajak.

Pengaruh mediasi kepercayaan masyarakat terhadap otoritas pajak pada hubungan keadilan prosedur terhadap kepatuhan pajak bise terlihat pada gambar dua. Pengeruh hubungan tersebut signifikan ini bisa dilihat pada nilai $P$ value kecil dari 0,01 dengan nilai Beta 0,34 yang menunjukan bahwa adanya penurunan nilai beta (pengaruh langsung 0.48, pada gambar satu) hal ini mengindikasikan bahwa kepercayaan mampu menjadi variabel mediasi/antara pada hubungan keadilan pada kepatuhan pajak, tetapi memediasi secara parsial ini menunjukan bahwa kepercayaan bukan satusatunya faktor yang dapat memediasi keadilan terhadap kepatuhan pajak tetapi terdapat faktor lain (Baron dan Kenny, 1986 dalam Sholihin dan Dwi, 2013).

Berdasarkan hasil analisis penelitian ini mendukung heuristik teory yang menyatakan bahwa masyarakat lebih merasakan keadilan dari otoritas perpajakan akan mempengaruhi tingkat kepercayaan masyarakat sehingga tingkat kepatuhan pajak juga akan mengalami peningkatan. Kepercayaan merupakan salah satu dari aspek yang membangun kehidupan sosial yang merupakan sebuah elemen dari realitas sosial. Slippery slope model (Kirchler, et al. 2008) mendukung teori fairness heuristic kebijakan untuk meningkatkan kepatuhan sukarela tergantung pada tingkat kepercayaan masyarakat pada otoritas pajak. Masyarakat yang merasakan keadilan akan patuh terhadap kewajiban perpajakan tetapi dengan adanya kepercayaan masyarakat terhadap otoritas pajak kepatuhan yang muncul tidak hanya kepatuhan yang dipaksakan tetapi akan memunculkan kepatuhan sukarela.

Selain mendukung teori penelitian ini juga mendukung hasil penelitian terdahulu seperti Murphy (2004), Gobeno dan Marius (2015) Oleh karena itu keadilan akan mempengaruhi tingkat kepatuhan pajak melalui adanya kepercayaan masyarakat terhadap otoritas pajak.

\section{SIMPULAN}

Berdasarkan hasil pengujian dalam penelitian ini dapat disimpulkan (1) Hasil pengujian empiris menunjukkan bahwa keadilan prosedur berpengaruh terhadap kepatuhan pajak, sehingga $\mathrm{H}_{1}$ terdukung. Hasil ini sesuai dengan hasil penelitian sebelumnya yang dilakukan oleh Gobena dan Marius (2015), Murphy (2004) dan Tyler (1997), dan Wenzel (2002). (2) Hasil pengujian empiris menunjukkan bahwa keadilan prosedur berpengaruh terhadap kepatuhan pajak melalui adanya kepercayaan masyarakat terhadap otoritas pajak, sehingga 
$\mathrm{H}_{2}$ terdukung. Hasil ini sesauai dengan hasil penelitian yang telah dilakukan oleh Murphy (2004), Gobeno dan Marius (2015).

\section{DAFTAR PUSTAKA}

Budiningrum, E.W. 2014. Pengaruh Norma Norma Sosial Terhadap Perilaku Kepatuhan Pajak Usaha Mikro, Kecil, dan Menengah (UMKM). Tesis, Universitas Gadjah Mada, Bekasi.

Campin Suzanne, Jo Barraket, dan B. L. (2013). Micro-Business Community Responsibility in Australia: Approaches, Motivations and BarriersNo Title. Journal of Business Ethics, 115, 418513.

Chen, D., F. C. Lee dan J. Mintz. 2002. Taxation, SMEs and Entrepreneuship. STI Working Paper. 19.

Gobene, Lesmassa Bayissa dan Marius Van Dijke. 2015. Power, justice, and Trus: A Moderated Mediation Analysis of Tax Compliance Among Ethopian Business Owners. Journal Of Economic Psyhology, 52 (2016) 23-37.

Hair, J. F., Willam, C. B., Barry, J. B., dan R. E. A. (2014). Multivariate Analysis. England: Pearson Education Limited.

Harinurdin Erwin. 2009. Perilaku Kepatuhan Wajib Pajak Badan, Bisnis \& Birokrasi. Jurnal Ilmu Administrasi dan Organisasi, Mei-Agustus. 16 (2): 96104.

Hendricks, K., R. Amit dan D. Whistler. 1997. Business Taxation of Small and Medium-sized Enterprises in Canada. Ottawa: Department of Finance Working Paper: 97-11.

Kamleitner, B., C. Korunka dan E. Kirchelr (2010). Tax compliance of small business owners A review. International Journal of Behavior \& Research 18(3): 330-351

Kamus Besar Bahasa Indonesia online. (n.d) Retrieved Oktober 22, 2013, from http://kamusbahasaindonesia.org/patuh

Kirchler, E., \& Wahl, I. (2010). Tax compliance inventory tax-I: Designing an inventory for surveys of tax compliance.Journal of Economic
Psychology, $31(3), 331-$ 346.http://dx.doi.org/10.1016/j.joep.201 0.01 .002

Laporan Keuangan Pemerintah Pusat Tahun 2012 (Audited). Mei 2013.

Lind, E. A. 2001. Fairness heuristic theory: Justice judgements as pivotal cognitions in organizational relations. In J. Greenberg \& R. Cropanzano (Eds.), Advances in organizational justice. Stanford, US: Stanford University Press.

Murphy, K. 2004. The role of trust in nurturing compliance: A study of accused tax avoiders. Law and Human Behavior, 28, 187-209

Molero, J., C., dan Pujol, F. 2012.Walking Insede the Potential Tax Evader's Mind: Moral perpajakan Does Matter. Journal Bussnis Ethics 105:151-162.

Peraturan Pemerintah Republik Indonesia, Nomor 46 Tahun 2013, Tentang Pajak Penghasilan atas Penghasilan dari Usaha yang Diterima atau Diperoleh Wajib Pajak yang Memiliki Peredaran Bruto Tertentu.

Pertiwi, D.,. 2013. Memahami Penyebab Kepatuhan Pajak: Faktor-faktor Perilaku Manusia. Skripsi: FEB UGM.

Praag. C. M., dan Peter H., V. 2007. What Is the Value of Entrepreneurship? A

Review of Recent Research. Small Business Economics. 29 (4): 351-382.

Pratiwi, Inung. 2015. Komitmen Manajemen, Implementasi Sistem Pengukuran Kinerja, Akuntabilitas Dan Kinerja Organisasi Publik Dalam Perspektif Teori Institusional Dan Teori Strukturasi. Skripsi: Universitas Gadjah Mada.

Sholihin Mahfud, Dwi Ratmono. 2013. Analisi SEM-PLS dengan WarpPLS 3.0 Untuk Hubungan Nonlinear dalam Penelitian Sosial dan Bisnis. Andy Offset Bekasi

Tyler, T. R. 2008. The psychology of legitimacy. A relational perspective on voluntary deference to authorities. Personality and Social Psychology Review, 1, 323-345. 
Undang-Undang Republik Indonesia Nomor 20 Tahun 2008 Tentang Usaha Mikro, Kecil, dan Menengah.

Verboon, P dan van Dijke, M. 2011. When do severe sanctions enhance compliance? The role of procedural fairness. Journal of Economic Psychology 32 hal 120-130 Wenzel, M. 2004. The Social Side of Sanction: Personal and Social Norm as
Moderators of Deterence. Law and Human Behavior, 28, 547-567.

Zatnika, A., M. 2014. Penerimaan Pajak 2013 Pendapatan pajak UKM 2013 capai Rp 328,94 triliun. http://nasional.kontan.co.id/news/penda patan-pajak-ukm-2013-capai-rp-32894triliun. Diakses 17 September 2014. 